\title{
“FIRST HOME” - A BANKING PRODUCT OR A SOCIAL PRODUCT?
}

\author{
Diana Magdalena Prihoancă \\ "Vasile Alecsandri" University of Bacău \\ dianaprihoanca@yahoo.com
}

\begin{abstract}
Under the conditions of the economic crises, the "First Home" program was launched on the banking market in Romania in 2009 - a banking product with strong social implications guaranteed by its advantages. In this paper, the "first home" product is presented through the legislative aspects that regulate its presence on the market, as well as its evolution from the launching moment to present.
\end{abstract}

\section{Keywords}

banking market; banking product; social product; guarantee fund; collaterals granted

\section{JEL classification}

M31; M38

The product is approached in marketing as a response for a certain need or problem which the client faces, an activity whereby a services is rendered to the consumer. A simple presentation of the physical characteristics of a product is not enough. It is important to highlight the competitive advantage it ensures (Cetină, 2007).

Defined in the specialty literature as representing the entirety of elements triggering the consumer's demand, the product concept finds a great confirmation in the service sector marketing. The classical sense within which the product appears as "an amount of attributes and tangible physical and chemical characteristics reunited in an identifiable form" correlated with the intangibility of the services led to the extension of the product coordinates beyond the usefulness perceived by the consumer, to the process of creation and delivery of the service and of all elements contributing to its development. From such point of view, some authors suggested to replace the term "product” with "service offer" (Olteanu, 2001).

The banking product - an element of the mix of traditional marketing - is that product/service which the banks must identify, create and make available to the clients, product/service which must correspond to their needs. In the banking institution, the product and service concepts have become interdependent and interexchangeable, being used to describe what the consumer is being offered (Cetină, Odobescu, 2007).

Therefore, the financial-banking services include within "the product" the elements of the performance process: the contact persons, buildings and equipment, the client as a participant in the performance, the technology of the creation and delivery of services (Olteanu, 2004).

As regards the social product, Philip Kotler believes there are three categories of social products: ideas, behaviors and tangible objects. A characteristic found in most of these products is their immateriality: the social organizations offer services, try to enforce ideas or to change behaviors and, only in few cases, offers material goods to the target groups (Zaharia, 2001).

This paper reflects the evolution on the financial banking market of a product which, by its characteristics, has had and has a role, at least at psychological level, both on 
the real estate market and banking market. The "First Home" product may be defined as a product initiated by the Government of Romania with the purpose of supporting the priority economic sectors, the main goal being to unblock the crediting activity and to give an impulse to the housing construction sector.

The "First Home" product was launched on the banking market in the summer of 2009, thus:

- May 20 2009 - the Government of Romania approved the "First Home" program, whose purpose was to offer a support to those clients who wanted to buy a dwelling but didn't have enough funds or didn't have collaterals and here originates the question whether this is a social product;

- June $4^{\text {th }}, 2009$ - the Emergency Ordinance no. 60/2009 on certain measures for the implementation of the "First Home" program was published in the Official Gazette;

- June $14^{\text {th }}$, 2009 - the implementation rules for the "First Home" program were approved, being defined the conditions which the beneficiaries of the program must meet;

- June $25^{\text {th }}, 2009$ - the list of the banking institutions involved in the program was completed.

The beginning of sales was the apogee of the entire preparation and launching process of the new product on the market, the beginning of its decisive confrontation with the users (Balaure et al, 2002). In the "First Home" case, the first credit agreement was concluded on July $8^{\text {th }}$, 2009. The credit for purchasing a new two-room dwelling in Colentina District in Bucharest was granted by BRD. The dwelling cost EUR 54,000, the credit value was EUR 43,000 for 30 years with EUR 307 monthly rate.

In order to obtain a dwelling through the "First Home" program, the clients must undergo seven stages (web source):

- $\quad$ submission of the financing application;

- $\quad$ analysis of eligibility, according to the banking rules;

- $\quad$ application for the guarantee from the National Credit Guarantee Fund for Small and Medium Enterprises (FNGCIMM);

- $\quad$ analysis of the application for the guarantee by FNGCIMM;

- grant of the guarantee to the bank by FNGCIMM;

- $\quad$ approval of the client's file;

- $\quad$ registration of the mortgage, by the bank, on the behalf of the state.

Four stages of this program have developed until now and the fifth stage is in progress, according to the following table:

\section{Table 1 Development of the "First Home" program on the banking market}

\begin{tabular}{|c|c|c|}
\hline Item & Year, month & Stage \\
\hline 1. & 2009, June & „first home” 1 program \\
\hline 2. & 2010, July & „first home” 2 program \\
\hline 3. & 2011, January & „first home” 3 program \\
\hline 4. & 2011, June & „first home” 4 program \\
\hline 5. & 2013, January & „first home” 5 program 5 \\
\hline Source: data operated according to www.imopedia.ro
\end{tabular}

The dwellings for which "First Home" credit agreements may be concluded are:

- $\quad$ finished dwellings, intended for purchase, including those built and put into operation through NHA programs;

- not finished dwellings, under various construction stages, intended for purchase after being finished, including those built through NHA programs;

- $\quad$ new dwellings, intended for purchase after being finished, including those built through NHA programs. 
Once the fourth stage started, the following types of dwelling add to the above mentioned ones:

- dwellings that are to be built by individual beneficiaries, including those that are built through NHA programs;

- dwellings that are to be built by associations without legal personality consisting of minimum two beneficiaries. The mandatory condition is that at least one of them must be the owner of the land which the collective dwelling is built on.

In legal terms, the "First Home" program is regulated by the following regulatory documents:

- Government Emergency Ordinance no. 60/2009, mention above;

- Government Decision no. 717/2009 on the approval of the implementation rules of the "First Home" program, as further amended and completed;

- Government Emergency Ordinance no. 30/2010, which amends and completes the previous ordinance in order to implement the second stage of the program;

- $\quad$ Government Emergency Ordinance no. 33/2011 amends and completes art. 1 of the Government Emergency Ordinance no. 60/2009, by adopting measures in order to continue the "First Home" program;

- Government Decision no. 40/2011, which amends and completes the implementation rules of the program;

- Government Decision no. 566/2013, on the allocation of a new ceiling of RON 1.2 billion, out of which 500 million are destined to the purchase of dwellings built by National Housing Agency.

The funds allocated for the first stage of the program were EUR 1 billion and they were fully used. Out of the EUR 700 million allocated for the second stage, only EUR 500 million were used, the rest of EUR 200 million being allocated to the third stage. The table below shows the indicators defining the development of the "First Home" program.

Table 2 Number of collaterals granted and their average value

\begin{tabular}{|l|l|r|r|r|}
\hline Item & \multicolumn{1}{|c|}{ Program } & \multicolumn{1}{|c|}{$\begin{array}{c}\text { Ceiling } \\
\text { established } \\
\text { - mil. euro - }\end{array}$} & $\begin{array}{c}\text { Collaterals } \\
\text { granted }\end{array}$ & \multicolumn{1}{c|}{$\begin{array}{c}\text { Average value of } \\
\text { the collaterals } \\
\text { - euro - }\end{array}$} \\
\hline & "first home" 1 & 1,000 & 18,554 & 41,574 \\
\hline & "first home" 2 & 700 & 16,414 & 40,133 \\
\hline & "first home" 3 & 200 & 5,114 & 39,015 \\
\hline $\begin{array}{l}\text { "first home" 4 } \\
\text { (June 1 } 1^{\text {st }}-\text { December 31 } \\
\text { 2011) }\end{array}$ & 771 & 15,034 & 38,000 \\
\hline
\end{tabular}

Source: data operated according to www.businessday.ro

From the total of the collaterals accessed until the end of the third stage of the program, most of them have been in Bucharest, $30.2 \%$ of the total number of collaterals, with a collateral average value of EUR 48,516. It is followed by Cluj County, with $7.5 \%$ of the total number of the collaterals (table no. 4). Each of Iasi, Brasov, Sibiu and Dolj counties has approximately $4 \%$ of the total number of collaterals granted, with a collateral average value under EUR 40,000. 
Table 3 Top of the counties according to the number of the collaterals granted

\begin{tabular}{|c|l|r|r|}
\hline Item. & County & $\begin{array}{c}\text { Collaterals granted } \\
-\%-\end{array}$ & $\begin{array}{c}\text { Average value of the } \\
\text { collaterals } \\
\text {-Euro- }\end{array}$ \\
\hline 1. & Bucharest & 30.2 & 48,516 \\
\hline 2. & Cluj & 7.5 & 36,912 \\
\hline 3. & Timis & 5.6 & 41,764 \\
\hline 4. & Ilfov & 5.1 & 49,165 \\
\hline 5. & Constanta & 4.7 & 42,319 \\
\hline \multicolumn{4}{|c|}{ Source: data operated according to $w w w . f n g c i m m . r o$} \\
\hline
\end{tabular}

According to the granting value of the "First Home" product, the distribution thereof is as follows:

- $\quad$ credits between EUR 50,000 and 60,000 - 31\% of the total of the concluded credit agreements;

- $\quad$ credits between EUR 40,000 and 50,000 - 20\% of the total of the concluded credit agreements;

- credits between EUR 30,000 and 40,000 - 24\% of the total of the concluded credit agreements;

- credits under EUR 30,000 - 251\% of the total of the concluded credit agreements;

The actors acting on the banking market in the case of the "First Home" product are as follows:

- $\quad$ Ministry of Public Finances, Ministry of Economy, Commerce and Business Environment, which sign a joint order for the program implementation;

- $\quad$ FNGCIMM, Romanian Association of Banks and the Partner Banks, which set the content of the frame collaboration convention, so that the program develops in optimum conditions;

- $\quad$ The clients.

FNGCIMM role on the banking market consists in calculating the maximum value of the collaterals in the following manner:

a. for finished dwellings, intended for purchase, including those built and put into operation through the programs implemented by NHA and for the unfinished dwellings in various building stages, intended for being purchased after completion, including those built through the programs implemented by NHA:

- Maximum 95\% of the purchase price provided for in the pre-sale contract, if the purchase price of the dwelling is lower than or equal to EUR 60,000, but not higher than the value resulted from the evaluation report;

- Maximum EUR 57,000, if the purchase price of the dwelling is higher than EUR 60,000, but not higher than the value resulted from the evaluation report.

b. for the new dwellings, intended for being purchased after completion, including those built through the programs implemented by NHA:

- $\quad$ Maximum 95\% of the purchase price provided for in the pre-sale contract, but not higher than the value resulted from the dwelling evaluation report, if the purchase price of the dwelling is lower than or equal to EUR 70,000;

- Maximum EUR 66,500, but not higher than the value resulted from the evaluation report, if the purchase price of the dwelling is higher than EUR 70,000 .

c. for collective dwellings, which are to be built through associations without legal personality, consisting of minimum two beneficiaries: 
- maximum 95\% of the value provided for in the dwelling building contract, lower than or equal to EUR 75,000, but not higher than the value resulted from the works cost estimate, an appendix to the dwelling building contract;

- maximum EUR 71,250, but not higher than the value resulted from the works cost estimate, if the value of building the dwelling is higher than EUR 75,000 .

Within the "First Home" 2 program, 21 banks sent offers to FNGCIMM, the total value of the ceiling requested by the banks exceeding with almost $50 \%$ the total approved ceiling for 2010 of EUR 700 million. The over-subscription of the allocated ceiling imposed the distribution of this ceiling through a progressive decrease, adequate to the subscription. The amounts distributed to the participating banks are presented in the table below.

Table 4 The amounts distributed to the banks within the "First Home" 2 program

\begin{tabular}{|c|l|r|}
\hline Item & Name of the Bank & $\begin{array}{c}\text { Allocated ceiling } \\
\text { - euro - }\end{array}$ \\
\hline 1. & BCR & $215,633,423$ \\
\hline 2. & BRD & $161,725,067$ \\
\hline 3. & Banca Românească & $53,908,356$ \\
\hline 4. & Alpha Bank & $45,822,102$ \\
\hline 5. & Piraeus Bank & $37,735,849$ \\
\hline 6. & Banca Transilvania & $26,954,178$ \\
\hline 7. & CEC Bank & $21,563,342$ \\
\hline 8. & Millenium & $18,867,925$ \\
\hline 9. & Raiffeisen & $16,172,507$ \\
\hline 10. & Banc Post & $16,172,507$ \\
\hline 11. & Unicredit & $16,172,507$ \\
\hline 12. & Intesa Bank & $13,477,089$ \\
\hline 13. & Garanti Bank & $13,477,089$ \\
\hline 14. & Volksbank & $10,781,671$ \\
\hline 15. & OTP Bank & $6,738,544$ \\
\hline 16. & Emporiki Bank & $6,469,003$ \\
\hline 17. & Leumi Bank & $5,390,836$ \\
\hline 18. & Credit Europe & $5,390,836$ \\
\hline 19. & Banca Carpatica & $4,312,668$ \\
\hline 20. & ATE Bank & $2,156,334$ \\
\hline 21. & RIB & $1,078,167$ \\
\hline 22. & TOTAL & $700,000,000$ \\
\hline & Source: www.fngcimm
\end{tabular}

Source: www.fngcimm.ro

Even if in the fourth stage, the partner banks within the "First Home" program will guarantee $50 \%$ of the value of the credits granted, a number of 21 financial institutions have concluded the collaboration contract with FNGCIMM:

The clients who can purchase a "First Home" dwelling can be (web source):

- natural persons who don't have a dwelling, individually or together with their spouses or other persons, regardless of the way the respective property has been acquired, except for the shares of the dwellings acquired by inheritance, and who have not purchased a dwelling after this date, regardless of the acquiring method;

- $\quad$ persons who don't have a valid mortgage;

- $\quad$ persons or families who comply with the terms imposed by the financier;

- persons who have a minimum of $5 \%$ advance of the purchase price of the dwelling;

- persons who, within this program, purchase a finished dwelling, which is on our country's territory, registered with the land registry and unencumbered; 
- persons who undertake to constitute a collateral to guarantee the interest, equal to three rates of interest;

- $\quad$ the tenants who have lived for at least one year in the dwellings built through NHA will be able to buy them.

The "First Home" program has a maximum ceiling regulated, in terms of legislation, and this is as follows:

- $\quad$ EUR 60,000 - for an old dwelling;

- $\quad$ EUR 70,000 - for a new dwelling;

- $\quad$ EUR 75,000 - for a collective dwelling built from scratch;

The clients who wish to purchase a more expensive dwelling will have to pay for the difference in full, at the signing of the contract.

Also, besides the $5 \%$ advance from the value of the estate, the client must pay a fee of 0.49\% per year to FNGCIMM. In the first three stages of the "First Home" program, the collateral granted by the state was $100 \%$, and once the fourth stage was launched, that collateral decreased to $50 \%$, and the participating banks will assume in proportion of $50 \%$ the risk of failure to repay the credit. In this variant, the "First Home" product can be bought also by the owners who possess a dwelling of a useful surface smaller than 50 sqm, provided they buy a dwelling of a bigger surface.

The fifth stage of the governmental project required the granting of the loans in national currency only, Romanian Commercial Bank being the first who adopted this new program.

Even if, from the moment when the "First Home" program has been launched until the present moment, the price of the dwellings (both old and new) has decreased, the product enjoyed further demand. The bidders from the new built real estate market adjusted to the credit criteria of the governmental program, and the two and threeroom apartments can be easily found at prices under EUR 60,000.

Comparing to July 2011, in July 2012 the old apartments at the national level were cheaper with $5 \%$. The increasing trend was felt in the big cities, as one can see in the tables below:

Table 5 The evolution of the prices of old apartments in Bucharest and ClujNapoca

\begin{tabular}{|l|c|c|c|r|r|r|}
\hline \multirow{3}{*}{$\begin{array}{c}\text { Apartment } \\
\text { Type }\end{array}$} & \multicolumn{3}{|c|}{ Bucharest } & \multicolumn{3}{c|}{ Cluj-Napoca } \\
\cline { 2 - 7 } & $\begin{array}{c}\text { July 2011 } \\
\text { - Euro } \\
\text { sqm - }\end{array}$ & $\begin{array}{c}\text { July 2012 } \\
\text { - Euro } \\
\text { sqm - }\end{array}$ & $\begin{array}{c}\text { Evolution 12 } \\
\text { months } \\
- \text { \% - }\end{array}$ & $\begin{array}{c}\text { July 2011 } \\
\text { - Euro } \\
\text { sqm - }\end{array}$ & $\begin{array}{c}\text { July 2012 } \\
\text { - Euro } \\
\text { sqm - }\end{array}$ & $\begin{array}{c}\text { Evolution 12 } \\
\text { months } \\
\text { - \% - }\end{array}$ \\
\hline 1 room & 1,181 & 1,089 & -7.8 & 962 & 1029 & 7.0 \\
\hline 2 rooms & 1,128 & 1,095 & -2.9 & 994 & 987 & -0.7 \\
\hline 3 rooms & 1,080 & 1,010 & -6.5 & 972 & 938 & -3.5 \\
\hline
\end{tabular}

Table 6 The evolution of the prices of old apartments in Constanta and Timisoara

\begin{tabular}{|l|c|c|c|c|c|c|}
\hline \multirow{3}{*}{$\begin{array}{c}\text { Apartment } \\
\text { Type }\end{array}$} & \multicolumn{4}{|c|}{ Constanta } & \multicolumn{3}{c|}{ Timisoara } \\
\cline { 2 - 7 } & $\begin{array}{c}\text { July 2011 } \\
\text { - Euro } \\
\text { sqm - }\end{array}$ & $\begin{array}{c}\text { July 2012 } \\
- \text { Euro } \\
\text { sqm - }\end{array}$ & $\begin{array}{c}\text { Evolution 12 } \\
\text { months } \\
- \text { \% - }\end{array}$ & $\begin{array}{c}\text { July 2011 } \\
\text { - Euro } \\
\text { sqm - }\end{array}$ & $\begin{array}{c}\text { July 2012 } \\
\text { - Euro } \\
\text { sqm - }\end{array}$ & $\begin{array}{c}\text { Evolution 12 } \\
\text { months } \\
\text { \% - }\end{array}$ \\
\hline 1 room & 946 & 917 & -3.1 & 922 & 854 & -7.4 \\
\hline 2 rooms & 944 & 857 & -9.2 & 830 & 786 & -5.3 \\
\hline 3 rooms & 966 & 883 & -8.6 & 758 & 759 & 0.1 \\
\hline
\end{tabular}

Source: $w$ ww.imobiliare.ro

The growth on the real estate market of the analyzed cities was registered only on the segment of one-room apartments in Cluj-Napoca and 3-room apartments in 
Timisoara, even if it is only of $0.1 \%$. The biggest price decrease, during the analyzed period, took place in Constanta for the two-room apartments.

The credit distribution for the "First Home" product, according to the number of rooms of the purchased dwelling is as follows (web source):

- three rooms - 26\%;

- $\quad$ two rooms $-51 \%$

- $\quad$ one room - $23 \%$.

Although in the launching moment, the "First Home" product aimed to stimulate the building of new dwellings during the economical crisis, that aim was partially reached, because only $28 \%$ of the total of the credit contracts are concluded for dwellings built after 2008, and only 3\% of the purchased dwellings are new, built "from scratch". The National Housing Agency sold only 320 dwellings within all stages of project implementation.

Even if the "First Home" product cannot be defined as a social product, according to the definition given within this article, we can say it is a product with an important social impact, because through its advantages ( $5 \%$ advance compared to the standard advance of $25 \%$ for the mortgage credits, the collateral granted by the state) it was especially conceived for a difficult economic period and offered the chance to buy a dwelling to the social categories with an average income).

\section{References}

Balaure, V. et al (2002), Marketing, Bucureşti, Editura Uranus.

Cetină, I. (2007), Marketing mix in Banking Industry, Revista de Marketing Online, $1(4)$.

Cetină, I., Odobescu, E. (2007), Strategii de marketing bancar, București, Editura Economică.

Data sets available on www.businessday.ro, www.brd.ro, www.fngcimm.ro, www.imobiliare.ro, www.imopedia.ro.

Zaharia, R. (2001), Marketing social-politic, Bucureşti, Editura Uranus. 